\title{
Implications of a new, biostratigraphically well- controlled, radio-isotopic age for the lower Telychian Stage of the Llandovery Series (Lower Silurian, Sweden)
}

\author{
1 School of Earth Sciences, Division of Geological Sciences, The Ohio State University, 155 S. Oval Mall, Columbus, Ohio 43210 , USA. \\ Email: stig@geology.ohio-state.edu \\ 2 Department of Geology, University of Cincinnati, Cincinnati, Ohio 45221, USA. \\ 3 Berkeley Geochronology Center, 2455 Ridge Road, Berkeley, California 94709, USA.
}

Radio-isotopic analysis of single zircons from two early Telychian K-bentonites, one of which is among the most widespread Lower Paleozoic volcanic ash falls in northern Europe, yields overlapping weighted mean ${ }^{206} \mathrm{~Pb}^{238} \mathrm{U}$ ages of $438.7 \pm 1.0 \mathrm{Ma}$ and $437.8 \pm 0.5 \mathrm{Ma}$, respectively. The former age is from zircons of the Osmundsberg K-bentonite from the type locality at Osmundsberget in the Siljan area of central Sweden where it occurs in the lower part of the Spirograptus turriculatus Graptolite Zone and in the lower part of the Angochitina longicollis Chitinozoan Zone. Zircons giving the latter age are from a bed previously identified as the Osmundsberg K-bentonite at the Kallholn Quarry in the same area. Based on new biostratigraphic data, the latter bed is now considered to be slightly younger than the Osmundsberg K-bentonite. The dated stratigraphic level of the ash layers is slightly younger than the base of the Telychian Stage and thus represents a minimum age for the Aeronian/Telychian Stage boundary. A U-Pb age of $>438$ Ma for the base of this stage, however, is older and in conflict with estimates in the most recent compilation of the Silurian time scale. In view of the fact that only three radio-isotopic dates from the entire Llandovery have been previously accepted, this new and biostratigraphically exceptionally well-controlled radio-isotopic date fills an important gap in the Lower Silurian geochronology.

\section{Introduction}

The geologic time scale is calibrated against radio-isotopic ages from different isotopic systems that are not necessarily comparable due to systematic biases arising from miscalibrated decay constants and standards. In addition, a large number of these ages are either hampered by analytical and/or statistical shortcomings or are biostratigraphically poorly constrained and hence of little use for the establishment of a robust geological time scale. As discussed below, arguably most of the published radio-isotopic ages for late Ordovician to early Silurian times are associated with such complications that are either not or insufficiently discussed in time scale compilations, highlighting the urgent need for new high-resolution radio-isotopic ages and more transparent evaluation in compilations. In the present study we present U-Pb zircon ages for biostratigraphically calibrated (graptolites and chitinozoans) K-bentonites, one of which can be assigned to the lower Telychian Spirograptus turriculatus Zone (Upper Llandovery). We also critically discuss some currently published Silurian ages that were included in a widely used compilation (Gradstein et al., 2004).

\section{The Osmundsberget locality}

In a regional study, Bergström et al. (1998a) and Huff et al. (1998) described the stratigraphic position, distribution, mineralogy, geochemistry, and various other aspects of the Osmundsberg K-bentonite. It was named for its type locality (Osmundsberget North) along the northern entrance road to the now disused Osmundsberget Quarry $\left(61^{\circ} 13^{\prime \prime N}, 15^{\circ} 12^{\prime} 4^{\prime \prime E}\right)$ in the Siljan region, Province of Dalarna, south-central Sweden (Figure 1). The Osmundsberg bed is $1.15 \mathrm{~m}$ thick at this locality and is accompanied in approximately 10 $\mathrm{m}$ of section by 8 additional K-bentonite beds that range between 1 and $32 \mathrm{~cm}$ in thickness (Huff et al., 1998). It is a bluish-gray clayrich unit that stands in contrast to the adjacent limestones and graptolitic shales (Figure 1). Regrettably, recent infilling of this road has almost completely destroyed this formerly splendid section, and further study of this prominent ash bed now requires considerable excavation. Fortunately, when this bed was fully exposed in the early 1990s, we carried out extensive sampling and the present study is based on these collections.

In the initial paper on the Osmundsberg K-bentonite (Bergström et al., 1998a), the biostratigraphy had to be based on the incomplete information that was available for this locality in the 1990s. Graptolites of the Stimulograptus sedgwickii Zone had long been recorded (Jaanusson, 1982; Thorslund and Jaanusson, 1960) from the basalmost part of the Kallholn Shale (Figure 2), which is a few meters below the interval of the Osmundsberg K-bentonite. From higher portions of the Kallholn Shale, including the interval of the Osmundsberg K-bentonite, there were records of Spirograptus turriculatus and other graptolites of the Spirograptus turriculatus Zone (Hutt et al., 1970). However, the level of the base of the latter graptolite zone remained undetermined until recently when Loydell and Maletz (2002) clarified the graptolite biostratigraphy in the section. Their data show that the interval from about $5 \mathrm{~m}$ to $9.5 \mathrm{~m}$ in the 


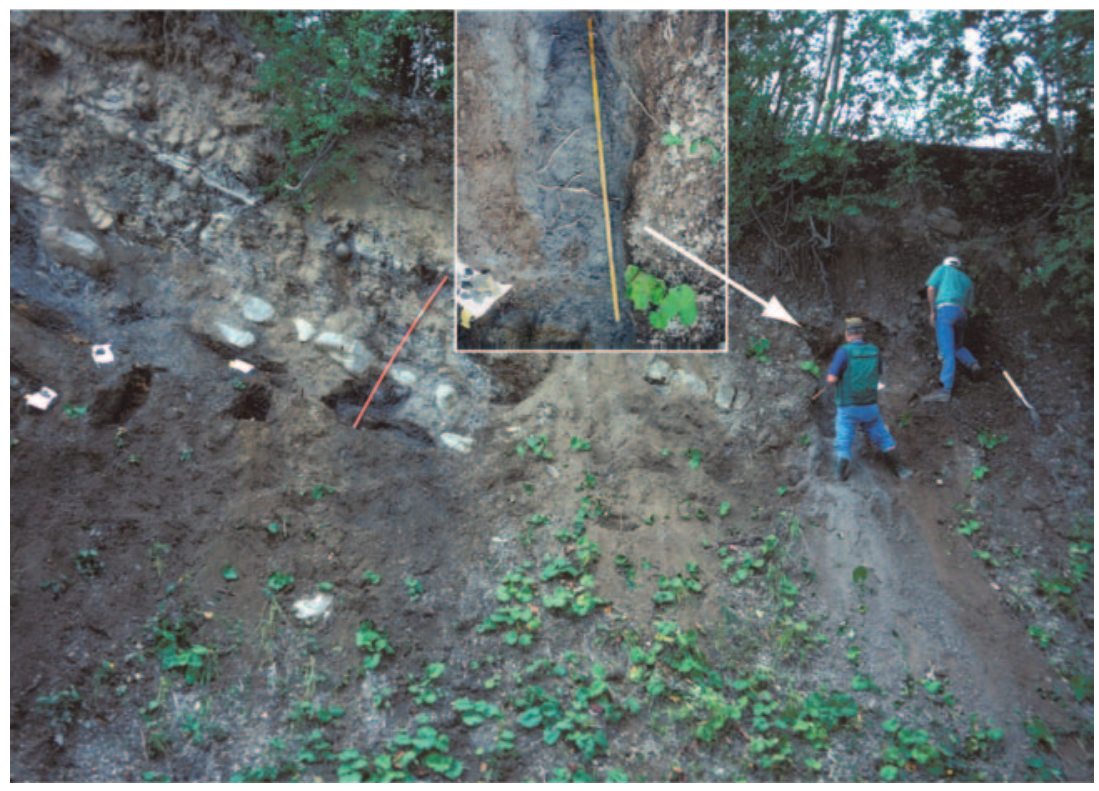

Figure 1 The Osmundsberg K-bentonite at its type locality along the northern entrance road to the Osmundsberget Quarry $\left(61^{\circ} 33^{\prime} 3^{\prime} N, 15^{\circ} 12^{\prime} 4^{\prime \prime E}\right)$ in the Siljan region, Province of Dalarna, south-central Sweden (1992 photograph).

section published by Bergström et al. (1998a, Figure 4) belongs in the Spirograptus guerichi Zone, and that $S$. turriculatus and other graptolites of that zone appear about $0.5 \mathrm{~m}$ below the base of the Osmundsberg K-bentonite (Figure 2). Loydell and Maletz (2002, Figure 2) also recorded the zonal index $S$. turriculatus about $0.5 \mathrm{~m}$ above the Osmundsberg K-bentonite, hence confirming the correctness of the original assignment of this prominent ash bed at its type locality to the $S$. turriculatus Zone. It should be stressed that the recent reference, without explanation, of this ash bed to the Aeronian S. sedgwickii Zone (Heatherington et al., 2004) is clearly in error.

Chitinozoans provide additional, although somewhat less precise, biostratigraphic data bearing on the age of the Osmundsberg K-

\section{OSMUNDSBERG NORTH}

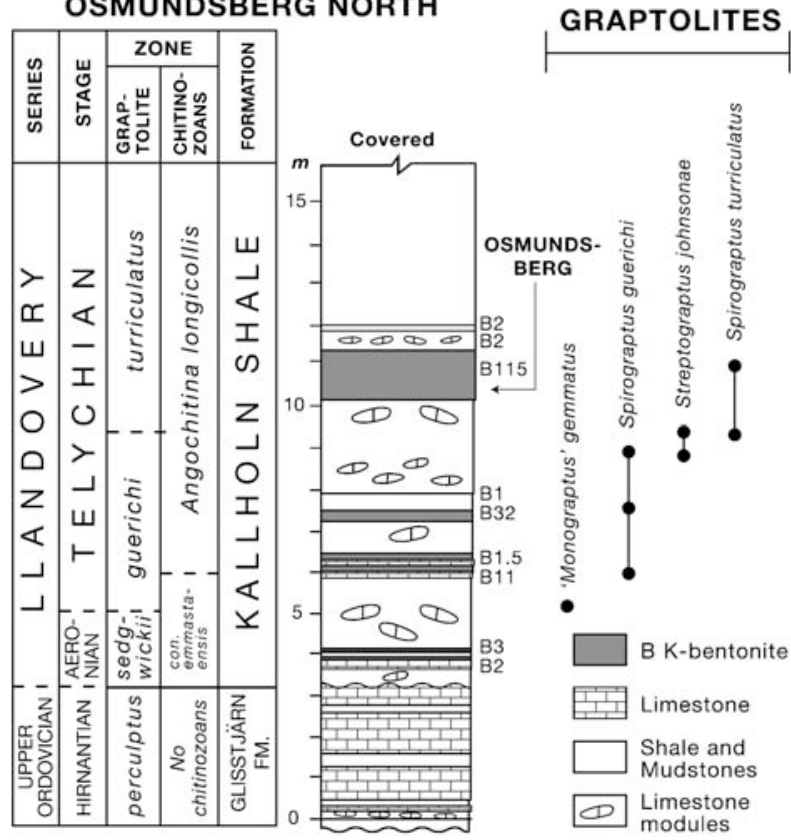

bentonite at Osmundsberget. In a regional study of Llandovery and Wenlock chitinozoan biostratigraphy of the Swedish mainland, Grahn (1998) investigated 13 samples from the Osmundsberget North (his Osmundsberget 1) section. His data show that the lower $2.5 \mathrm{~m}$ of the Kallholn Shale, which corresponds broadly to the 4-8 $\mathrm{m}$ interval in Bergström et al. (1998a, Figure 4), is referable to the Conochitina emmastensis Zone. The Osmundsberg K-bentonite occupies a position in the lower part of the overlying Angochitina longicollis Zone (Figure 2), the lower part of which has been shown to be of early Telychian age elsewhere (Grahn , 1998, Figure 15). Hence, the graptolite and chitinozoan evidence from this section is in excellent agreement and provides a firm biostratigraphic age dating of this volcanic ash bed. The known stratigraphic ranges of selected graptolites and chitinozoans and the chronostratigraphic classification of the Osmundsberg K-bentonite at its type locality are summarized in Figure 2.

\section{The Kallholn Quarry locality}

Bergström et al. (1998a) identified a potential Osmundsberg K-bentonite equivalent at another locality in the Siljan region, namely in the outcrop of the Kallholn Shale along the south side of the western entrance road to the inactive Kallholn Quarry $\left(61^{\circ} 10^{\prime} 0 " \mathrm{~N}, 14^{\circ} 41^{\prime} 60^{\prime \prime} \mathrm{E}\right)$. This section, which is about $30 \mathrm{~km}$ north-west of Osmundsberget, is clearly the exposure from which Loydell (1991) described taxonomically diverse and beautifully preserved graptolites of the Monograptus argenteus Zone. These graptolites, which were collected from limestone concretions in the lower two meters of the Kallholn Shale, are from the middle part of the Aeronian Stage and show that the base of this shale is slightly older biostratigraphically at this locality than at the Osmundsberget North section. The graptolite zone classification of the overlying major part of the Kallholn Shale, which has long been assumed to represent the $S$. sedgwickii and $S$. turriculatus zones, has yet to be firmly established. However, the chitinozoan biostratigraphic data from CHITINOZOANS the Kallholn Quarry published by Grahn (1998)

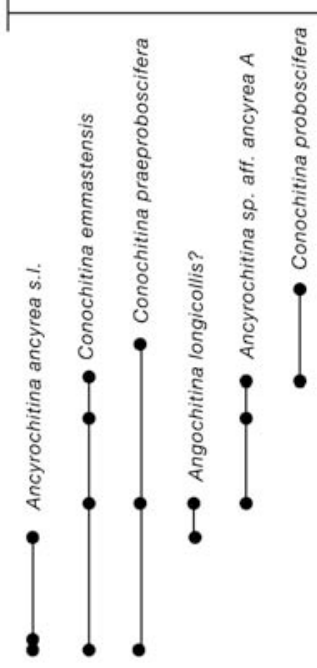
appear to suggest that the ash bed in this section identified as the Osmundsberg K-bentonite by Bergström et al. (1998a) may not be located within the $S$. turriculatus Zone, and hence, it would represent a different volcanic ash bed than the Osmundsberg K-bentonite. According to Grahn (1998), chitinozoans of the Ramochitina nestorae Subzone of the Angochitina longicollis Zone appear just a few $\mathrm{m}$ above the base of the Kallholn Shale in his Kallholn section. Because this subzone is of late Telychian age and interpreted to be no older than the Octavites spiralis Graptolite Zone (Grahn, 1998, Figure 15), this interval is significantly younger than that of the Osmundsberg K-bentonite.

However, there were some problems in using Grahn's data for our section. First, his Kallholn section is described as being located "in the south wall of the quarry", not along the entrance road, and there are at least two Kallholn Shale sections in the quarry. Second, Grahn's (1998, Figure 2) generalized lithologic $\log$ shows no similarity to that of our section (Bergström et al., 1998a, Figure 5), including the position of several K-bentonite beds. In view of these conflicting data, we were uncer-
Figure 2 Vertical ranges of selected graptolites (after Loydell and Maletz, 2002) and chitinozoans (after Grahn, 1998) and stratigraphic classification of the Osmundsberget North section. Note the biostratigraphic position of the Osmundsberg K-bentonite in the lower part of the S. turriculatus Zone. 
tain whether or not Grahn's section is the same as ours, and hence, if his chitinozoan data could be used for interpretation of the biostratigraphy of our section. However, observations made during a visit to the quarry in 2007 by two of us (WDH and SMB) left no doubt that Grahn's (1998) section is the same as that studied by us. Hence, there is biostratigraphic evidence that the studied K-bentonite at Kallholn is younger than the Osmundsberg K-bentonite. This conclusion is consistent with the fact that recent chemostratigraphic fingerprinting studies of the Osmundsberg K-bentonite (Toprak et al., in 0.0706 preparation) show differences to the Kallholn bed.

\section{New U-Pb zircon ages and analytical methods}

Samples SWE129 and SWE132 from the Osmundsberg and Kallholn localities, respectively, were subjected to standard mineral separation techniques for zircon extraction at University of Cincinnati. The sample yielded colorless, clear zircons of elongated prismatic or needle-like morphology with few inclusions. The crystals were carefully examined in transmitted light using a petrographic microscope. In order to avoid averaging effects caused by older inheritance, xenocrystic contamination and $\mathrm{Pb}$ loss, or a combination of all (Mundil et al., 2001), zircons were analyzed individually by low blank, isotope dilution thermal ionization mass spectrometry (IDTIMS) analytical techniques at the Berkeley Geochronology Center. Zircon crystals were annealed at $850^{\circ} \mathrm{C}$ and chemically abraded following the techniques described in Mundil et al. (2004) and Mattinson (2005) in order to minimize the effects of $\mathrm{Pb}$ loss. Subsequent to chemical abrasion crystal fragments were very small, weighing 0.3 to $0.8 \mu \mathrm{g}$, but contained sufficient $206 \mathrm{~Pb}_{\text {rad }}$ for precise analysis. Analytical protocols follow those described in Mundil et al. (2004). Individual isotopic ratios containing $206 \mathrm{~Pb}$ are

corrected for excess 230Th during the crystallization of the zircons (with an assumed $\mathrm{Th} / \mathrm{U}$ of 4 in the host rock) that results in an age bias of +84 Ka in average (Schärer, 1984).

As shown in Figure 3 and Table 1, four out of five analyzed zircons from the Osmundsberg locality (SWE129) yield a weighted mean ${ }^{206} \mathrm{~Pb} /{ }^{238} \mathrm{U}$ age of $438.7 \pm 1.0 \mathrm{Ma}$ (MSWD 0.2). One analysis is affected by old inheritance at ca $1500 \mathrm{Ma}$. SWE129 zircons have an average $\mathrm{U}$ concentration of $270 \mathrm{ppm}$, and $\mathrm{Th} / \mathrm{U}$ ranges from 0.58 to 0.82 . Six out of seven zircon analyses from SWE 132 yield a weighted mean ${ }^{206} \mathrm{~Pb} /{ }^{238} \mathrm{U}$ age of $437.8 \pm 0.5 \mathrm{Ma}$ (MSWD 0.3). The age of crystal Z06 is slightly older (445 Ma) but resolved from the remaining cluster, indicating the presence of xenocrysts. As for SWE129 the average $U$ concentration is $270 \mathrm{ppm}$ and $\mathrm{Th} / \mathrm{U}$ varies similarly between 0.55 and 0.74 .

Table 1 Isotopic ratios and analytical data for Osmundsberg zircons.

isotopic ratios

isotopic ages

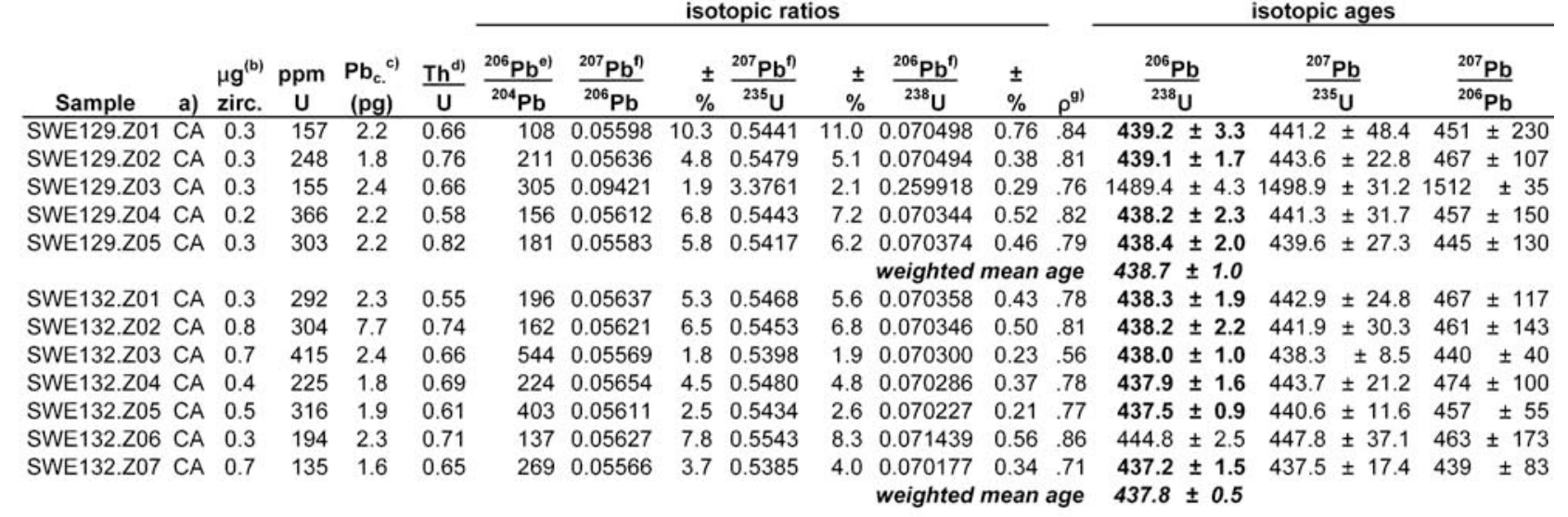

a) $\mathrm{CA}=$ annealed/chemically abraded

b) sample weight is calculated from crystal dimensions and is associated with as much as $50 \%$ uncertainty (estimated)

c) total common $\mathrm{Pb}$ including analytical blank (analytical $\mathrm{Pb}$ blank is $0.8 \pm 0.3 \mathrm{pg}$ per analysis). Blank composition is ${ }^{206} \mathrm{~Pb} /{ }^{204} \mathrm{~Pb}=18.55 \pm 0.63$,

${ }^{207} \mathrm{~Pb} /{ }^{204} \mathrm{~Pb}=15.50 \pm 0.55,{ }^{208} \mathrm{~Pb} /{ }^{204} \mathrm{~Pb}=38.07 \pm 1.56$ (all 2 ? of population), and a ${ }^{206} \mathrm{~Pb} /{ }^{204} \mathrm{~Pb}-{ }^{207} \mathrm{~Pb} /{ }^{204} \mathrm{~Pb}$ correlation of +0.9

${ }^{d)}$ present day $\mathrm{Th} / \mathrm{U}$ ratio calculated from radiogenic ${ }^{208} \mathrm{~Pb} /{ }^{206} \mathrm{~Pb}$ and age

e) measured value corrected for tracer contribution and mass fractionation $(0.15 \pm 0.09 \% / \mathrm{amu})$

${ }^{f}$ ratios of radiogenic $\mathrm{Pb}$ versus $\mathrm{U}$; data corrected for mass fractionation, tracer contibution and common $\mathrm{Pb}$ contribution

9) correlation coefficient of radiogenic ${ }^{207} \mathrm{~Pb} /{ }^{235} \mathrm{U}$ versus ${ }^{206} \mathrm{~Pb} /{ }^{238} \mathrm{U}$

Uncertainties of individual ratios and ages are given at the $2 \sigma$ level and do not include decay constant errors.

Ratios involving ${ }^{206} \mathrm{~Pb}$ are corrected for initial disequilibrium in ${ }^{230} \mathrm{Th} /{ }^{238} \mathrm{U}$ adopting $\mathrm{Th} / \mathrm{U}=4$ for the crystallization environment.

Weighted mean ${ }^{206} \mathrm{~Pb} /{ }^{238} \mathrm{U}$ ages (in italics) are calculated from individual ages in bold. 


\begin{tabular}{|c|c|c|c|c|c|}
\hline \multirow{2}{*}{$\begin{array}{l}\text { Age } \\
\text { (Ma) }\end{array}$} & \multicolumn{2}{|c|}{ Global } & \multirow{2}{*}{$\begin{array}{c}\text { Baltic } \\
\text { Regional } \\
\text { Stages }\end{array}$} & \multirow{2}{*}{ Graptolite Zones } & \multirow{2}{*}{$\begin{array}{c}\text { Radio-isotopic } \\
\text { ages }\end{array}$} \\
\hline & Series & Stages & & & \\
\hline \multirow{5}{*}{ 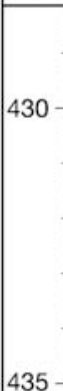 } & \multirow{12}{*}{ 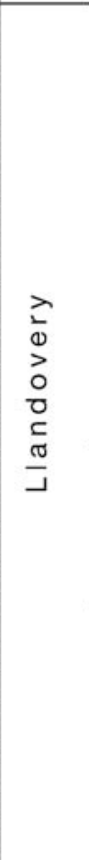 } & \multirow{5}{*}{ Telychian } & \multirow{5}{*}{ Adavere } & Cyrtograptus insectus & \multirow{12}{*}{$\begin{array}{l}\cdot 438.7 \pm 2.1 \mathrm{~Pb}-\mathrm{Pb}(3) \\
\cdot 439.4 \pm 5.0 \mathrm{Ar}-\operatorname{Ar}(4)\end{array}$} \\
\hline & & & & Oktavites spiralis & \\
\hline & & & & \begin{tabular}{|c|} 
Monoclimacis crenulata- \\
Monoclimacis griestoniensis \\
\end{tabular} & \\
\hline & & & & Monograptus crispus & \\
\hline & & & & $\begin{array}{c}\text { Spirograptus turriculatus } \\
\text { Spirograptus guerichi }\end{array}$ & \\
\hline & & \multirow{3}{*}{ Aeronian } & & $\begin{array}{l}\text { Stimulograptus sedgwickii } \\
\text { Lituigraptus convolutus }\end{array}$ & \\
\hline & & & \multirow{3}{*}{ Raikkula } & Monograptus argenteus & \\
\hline & & & & $\begin{array}{l}\text { Demirastrites pectinatus- } \\
\text { Demirastrites triangulatus }\end{array}$ & \\
\hline \multirow{4}{*}{ 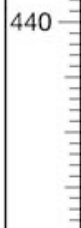 } & & \multirow{4}{*}{ Rhuddanian } & & Coronograptus cyphus & \\
\hline & & & \multirow{3}{*}{ Juuru } & Orthograptus vesiculosus & \\
\hline & & & & Parakidograptus acuminatus & \\
\hline & & & & Akidograptus ascensus & \\
\hline
\end{tabular}

Figure 4 Relations between the time scale of Melchin et al. (2004), chronostratigraphic units, and accepted radio-isotopic ages. Note the discordant correlation between some of the radio-isotopic ages and the age values in the time scale in the left part of the figure. Sources of radio-isotopic ages are as follows: (1) Buttington Shales, Wales (Tucker, 1991); (2) this paper; (3) Birkhill Shales, S. Scotland (Tucker et al., 1990); (4) Descon Formation, Esquibel Island, Alaska (Kunk et al., 1985). As indicated in the text, this radio-isotopic age is recalculated. Figure is a modification of part of a figure published by Melchin et al. (2004, figure 13.1).

Although the $\mathrm{U}-\mathrm{Pb}$ ages, $\mathrm{U}$ concentration and $\mathrm{Th} / \mathrm{U}$ of individual zircons from both samples are closely similar, their different biostratigraphic age indicates that they represent different ash falls as is also suggested by their different trace element composition.

\section{Review of previous ages and significance of the new radio-isotopic date}

Establishing a reliable and detailed time scale requires precise and accurate radio-isotopic ages of many biostratigraphically wellcontrolled horizons. As noted above, in the entire Llandovery there have been available only three radio-isotopic ages that have been considered to fulfill currently acceptable biostratigraphic requirements (Melchin et al., 2004, p. 198) but arguably, none of these ages stands up to scrutiny when tested for accuracy, let alone precision, illustrating the need for new high-resolution ages.

Two of the published ages accepted by Melchin et al., (2004) are from the same upper Rhuddanian graptolite zone and one (Tucker, 1991) is from a graptolite zone in the middle Telychian (Figure 4). No radio-isotopic date has been available from the Middle Llandovery Aeronian Stage or from a stratigraphic level close to any of the stage boundaries. Furthermore, the base and the top of the Llandovery Series in time scale compilations (Melchin et al., 2004) is based on extrapolations using values from levels several graptolite zones above and below these boundaries. In the case of the Ordovician/Silurian boundary, the youngest available Ordovician radio-isotopic date is a ${ }^{207} \mathrm{~Pb} / 206 \mathrm{~Pb}$ zircon age quoted at $445.7 \pm 2.4 \mathrm{Ma}$ (uncertainty expands to $\pm 4.7 \mathrm{Ma}$ if uncertainties for decay constants are included) for the Paraorthograptus pacificus Zone (Tucker et al., 1990), excluding 1 out of 4 multi-crystal analyses. It is not clear as to why one analysis was excluded and why this approach was chosen rather than calculating a more precise weighted mean ${ }^{206} \mathrm{~Pb} /{ }^{238} \mathrm{U}$ age including all analyses of $444.9 \pm 1.0$ Ma. The oldest published Silurian date from Tucker et al. (1990) is quoted at $438.7 \pm 2.1 \mathrm{Ma}( \pm 4.8 \mathrm{Ma}$ including decay constant uncertainties) and is assigned to the Coronograptus cyphus Zone, which is the fourth standard graptolite zone above this systemic boundary. Two out of six analyses are excluded, most likely because slightly older inheritance was suspected (although the two older ages are concordant). Since all ${ }^{206} \mathrm{~Pb} /{ }^{238} \mathrm{U}$ ages are overlapping, an age of $439.6 \pm 1.4$ Ma (MSWD 1.3) can also be calculated.

Even this older age calculated from ${ }^{206} \mathrm{~Pb} /{ }^{238} \mathrm{U}$ may be regarded as a minimum age and the scatter of data explained by varying amounts of $\mathrm{Pb}$ loss rather than inheritance. In any case, it is evident that the data in the Tucker et al. (1990) study can be interpreted in different ways yielding slightly different results. It should also be noted that the biostratigraphic assignment of the latter radio-isotopic date is not without problems. That is, the statement by Tucker et al. (1990, p. 55) that the dated K-bentonite was located about $60 \mathrm{~m}$ stratigraphically above the Ordovician-Silurian boundary is clearly wrong because the thickness of the entire Birkhill Shale at this locality, which ranges into the Telychian, is no more than $43 \mathrm{~m}$ and the interval of the C. cyphus Zone is about $6-13 \mathrm{~m}$ above the systemic boundary (Toghill, 1968). This error was noted by Cooper and Sadler (2004), who proposed that $60 \mathrm{~m}$ should be $6 \mathrm{~m}$, which would be a level at the very base of the C. cyphus Zone. However, in the lithologic descriptions of this zone (see, e.g., Toghill, 1968) there is no record of a $20 \mathrm{~cm}$ thick Kbentonite, but there is a prominent volcanic ash bed at the base of the overlying Demorastrites pectinatus- $D$. triangulatus (formerly C. gregarius) Zone and there is also a K-bentonite approaching this thickness in the Lituigraptus convolutus Zone (Bergström et al., 1998a). Clearly, confirmation of the biostratigraphic origin of this radio-isotopic date as well as re-analyzing zircons using modern single-crystal techniques are highly desirable.

Another radio-isotopic age date included in the most recent time-scale compilation (Cooper and Sadler, 2004, table 12.1) is an ${ }^{40} \mathrm{Ar} /{ }^{39} \mathrm{Ar}$ hornblende age of $439.4 \pm 5 \mathrm{Ma}$, which was recalculated from 436.2 $\pm 5.0 \mathrm{Ma}$ in Kunk et al. (1985), applying a revised age for MMhb-1 hornblende used as flux monitor (Renne et al., 1998). In addition, this age has to be corrected for a bias of ca $1 \%$ when compared to U-Pb ages, yielding ca $444 \mathrm{Ma}$, which Cooper and Sadler (2004) did not take into consideration (Min et al., 2000; Mundil et al., 2006). Also, the ${ }^{40} \mathrm{Ar} /{ }^{39} \mathrm{Ar}$ age is basically based on one single step, containing $82 \%$ of ${ }^{40} \mathrm{Ar}_{\text {rad }}$, in a four step spectrum, and is therefore very fragile and does not stand up to scrutiny after applying accepted data reduction protocols. Stratigraphically, the sample is from a sedimentary breccia in the Descon Formation of Esquibel Island, which is located about $320 \mathrm{~km}$ south of Juneau in southeastern Alaska. This date is problematic also in that it is poorly constrained biostratigraphically. Graptolites representing the C. cyphus Zone have been recorded about $4 \mathrm{~m}$ below the breccia (Churkin et al., 1970) but there is no direct biostratigraphic control of the breccia itself except that it presumably is older than a younger part of the Descon Formation from which Churkin and Carter (1970) obtained graptolites of the S. sedgwickii Zone, the youngest graptolite zone known from this thick formation. Hence, the Esquibel Island radioisotopic date is younger than a portion of the C. cyphus Zone and older that a part of the S. sedgwickii Zone, an interval corresponding to at least three standard graptolite zones. It is also appropriate to direct attention to the fact that the total thickness of the lowermost 
Silurian, including the C. cyphus Zone, is only about $5 \mathrm{~m}$ on Esquibel Island. If the same exceptionally slow rate of net deposition continued to prevail up to the base of the sedimentary breccia, the 4 $\mathrm{m}$ thick, apparently non-graptolite bearing, succession between the topmost graptolite collection and the base of the breccia could conceivably correspond to one, or even several, graptolite zones younger than the $C$. cyphus Zone. Accordingly, and even ignoring the analytical shortcomings, until better biostratigraphic control has become available, this radio-isotopic date should not be used unconditionally as representative of the age of the $C$. cyphus Zone. It is appropriate to note that this age appears to differ by as much as $4 \mathrm{Ma}$ from that of the Birkhill Shale K-bentonite despite the fact that they have been assumed to represent the same graptolite zone.

Direct radio-isotopic age control is even less robust for the Llandovery/Wenlock boundary, the youngest Llandovery date $(430.1 \pm 2.4 \mathrm{Ma}( \pm 4.8 \mathrm{Ma}$ including decay constant uncertainties $))$ being from the Monoclimacis crenulata Zone (Tucker, 1991; Tucker and McKerrow, 1995), which is the fourth graptolite zone below the top of this series. As mentioned above, the scatter of the data indicates the presence of $\mathrm{Pb}$ loss suggesting that the oldest ${ }^{206} \mathrm{~Pb} /{ }^{238} \mathrm{U}$ age of 433 Ma may be a minimum age.

The oldest post-Llandovery radio-isotopic date $(426.8 \pm 1.7$ Ma) (recalculated from $423.7 \pm 1.7 \mathrm{Ma}$ in Kunk et al. 1985, see above and Renne et al. (1998)) included in the most recent compilation by Melchin et al. (2004) is from the interval of the early Ludlow Neodiversograptus nilssoni-Lobograptus scanicus zones (Kunk et al., 1985), which is 9-10 graptolite zones above the top of the Llandovery. Recalculating this age from the data table given in Kunk et al. (1985) yields $425.0 \pm 2.2 \mathrm{Ma}$ (with an assumed uncertainty of $0.2 \%$ in $\mathrm{J}$ ), which must be adjusted to 427.9 Ma using the accepted age for MMhb-1 and ca $432.2 \mathrm{Ma}$ accounting for the additional $1 \%$ bias in order to compare it to U-Pb ages. Even in the absence of the discussed complications affecting the accuracy of these ages, the extrapolation to the top of the Llandovery from such stratigraphically widely separated horizons, which in this case amounts to an interval of at least 11 graptolite zones, results in very significant errors. Recently, a multigrain U-Pb zircon age of $433.2 \pm 1.6 \mathrm{Ma}$ was briefly reported from the Ireviken K-bentonite (Jeppsson et al., 2005), which is located just above the base of the Wenlock on the Island of Gotland, Sweden. However, the reliability of this age is difficult to assess until full documentation has been published.

Our new radio-isotopic ages, with excellent biostratigraphic control, provide important age control in a previously poorly calibrated stratigraphic interval of significant length (five graptolite zones) in the Llandovery (Figure 4). Furthermore, because the dated Osmundsberg horizon is only one graptolite zone above the Aeronian/Telychian Stage boundary, the new radio-isotopic date suggests that the radio-isotopic age of this stage boundary is only slightly older than $438 \mathrm{Ma}$. This age is older than hitherto postulated in all compilations, which is due to many published $\mathrm{U}-\mathrm{Pb}$ ages being affected by $\mathrm{Pb}$ loss resulting in inaccurate and slightly younger ages as well as biased ${ }^{40} \mathrm{Ar} /{ }^{39} \mathrm{Ar}$ ages due to a miscalibrated $\mathrm{K}$ decay constant and incorrect ages of flux monitors, also resulting in ages which are too young. The quality of the Silurian time scale is still in a highly provisional state and will only be improved when more precise and accurate radio-isotopic ages are available. In view of the many K-bentonites present in this series, particularly in northern Europe and eastern North America (Bergström et al., 1997; Bergström et al., 1998a, b), the potential for obtaining the required radio-isotopic ages is very promising. Until then, considerable caution is warranted in using the currently available radio-isotopic ages, in particular if they are extrapolated to represent true ages of zones and stages.

\section{Acknowledgements}

We are indebted to Steven Leslie for assistance in the field, to Nils Malmsten for providing a car for transportation in the Siljan region, and to Jan Bergström for arranging the shipping of the samples from Sweden to the USA. RM acknowledges support from the Ann and Gordon Getty foundation. The present research was supported in part by NSF grants EAR-9004559, EAR-9005333, EAR-9204893, and EAR- 9205981.

\section{References}

Bergström, S.M., Huff, W.D., Kolata, D.R., and Melchin, M.J., 1997, Occurrence and significance of Silurian K-bentonite beds at Arisaig, Nova Scotia, eastern Canada: Canadian Journal of Earth Sciences, v. 34, pp. 1630-1643.

Bergström, S.M., Huff, W.D., and Kolata, D.R., 1998a, The Lower Silurian Osmundsberg K-bentonite. Part I: Stratigraphic position, distribution, and palaeogeographic significance: Geological Magazine, v. 135, pp. $1-13$.

Bergström, S.M., Huff, W.D., and Kolata, D.R., 1998b, Early Silurian (Llandoverian) K-bentonites discovered in the southern Appalachian thrust belts, eastern USA: Stratigraphy, geochemistry, and tectonomagmatic and paleogeographic implications: GFF, v. 120, pp. 149-158.

Churkin, M., Jr., and Carter, C., 1970, Early Silurian graptolites from southeastern Alaska and their correlation with graptolitic sequences in North America and the Artic: U.S. Geological Survey Professional Paper 653, pp. $1-60$.

Churkin, M., Jr., Carter, C., and Eberlein, D., 1970, Graptolite succession across the Ordovician-Silurian boundary in southeastern Alaska: Quarterly Journal of the Geological Society of London, v. 126, pp. 319-330.

Cooper, R.A., and Sadler, P.M., 2004, The Ordovician Period, in Gradstein, F., Ogg, J., and Smith, A., eds., A Geologic Time Scale 2004, Cambridge University Press, pp. 165-187.

Gradstein, F., Ogg, J., and Smith, A., 2004, A Geologic Time Scale 2004, Cambridge University Press, 611 pp.

Grahn, Y., 1998, Lower Silurian (Llandovery-Wenlock) chitinozoa and biostratigraphy of the mainland of Sweden: GFF, v. 120, pp. 273-283.

Heatherington , C.J., Nakrem, H.A., and Batchelor, R.A., 2004, The Bjørntvet metabentonite: A new correlation tool for the Silurian of the southwest Oslo region: Norwegian Journal of Geology, v. 84, pp. 239-250.

Huff, W.D., Bergström, S.M., Kolata, D.R., and Sun, H., 1998, The Lower Silurian Osmundsberg K-bentonite. Part II: Mineralogy, geochemistry, chemostratigraphy, and tectonomagmatic significance: Geological Magazine, v. 135, pp 15-26.

Hutt, J., Rickards, R.B., and Skevington, D., 1970, Isolated Silurian graptolites from the Bollerup and Klubbudden stages of Dalarna, Sweden: Geologica et Palaeontologica, v. 4, pp. 1-23.

Jaanusson, V., 1982, The Siljan district, in Bruton, D.L., and Williams, S.H., eds., IV International Symposium on the Ordovician System, Field Excursion Guide: Paleontological Contributions from the University of Oslo, No. 279, pp. 15-42.

Jeppsson, L., Calner, M., and Eriksson, M.E., 2005, Locality descriptions, in Eriksson, M.E., and Calner, M., eds., The dynamic Silurian Earth. Subcommission on Silurian Stratigraphy, Field Meeting 2005, Field guide and abstracts: Geological Survey of Sweden, Rapporter och Meddelanden, v. 121, pp. 22-56.

Kunk, M.J., Sutter, J., Obradovich, J.D., and Lanphere, M.A., 1985, Age of biostratigraphic horizons within the Ordovician and Silurian systems, in Snelling, N.J., ed., The chronology of the geological record: British Geological Survey Memoir, v. 10, pp. 89-92.

Loydell, D.K., 1991, Isolated graptolites from the Llandovery of Kallholen, Sweden: Palaeontology, v. 34, pp. 671-693.

Loydell, D.K., and Maletz, J., 2002, Isolated 'Monograptus' gemmatus from the Silurian of Osmundsberget, Sweden: Geologiska Föreningens Stockholm Förhandlingar, v. 124, pp. 193-196.

Mattinson, J.M., 2005, Zircon U-Pb chemical abrasion ("CA-TIMS") method: Combined annealing and multi-step partial dissolution analysis for improved precision and accuracy of zircon ages: Chemical Geology, v. 220, pp. 47-66.

Melchin, M.J., Cooper, R.A., and Sadler, P.M., 2004, The Silurian Period, in Gradstein, F., Ogg, J., and Smith, A., eds., A Geologic Time Scale 2004 : Cambridge University Press, Cambridge, pp. 188-201.

Min, K., Mundil, R., Renne, P.R., and Ludwig, K.R., 2000, A test for systematic errors in ${ }^{40} \mathrm{Ar} /{ }^{39} \mathrm{Ar}$ geochronology through comparison with $\mathrm{U} / \mathrm{Pb}$ analysis of a 1.1-Ga rhyolite: Geochemica et Cosmochemica Acta, v. 64 , pp. 73-98. 
Mundil, R., Metcalfe, I., Ludwig, K.R., Renne, P.R., Oberli, F., and Nicoll, R.S., 2001, Timing of the Permian-Triassic biotic crisis: implications from new zircon $\mathrm{U} / \mathrm{Pb}$ age data (and their limitations): Earth and Planetary Science Letters, v. 187, pp. 131-145.

Mundil, R., Ludwig, K.R., Metcalfe, I., and Renne, P.R., 2004, Age and timing of the Permian mass extinctions: $\mathrm{U} / \mathrm{Pb}$ dating of closed-system zircons: Science, v. 305, pp. 1760-1763.

Mundil, R., Renne, P.R., Min, K., and Ludwig, K.R., 2006, Resolvable miscalibration of the ${ }^{40} \mathrm{Ar} /{ }^{39} \mathrm{Ar}$ geochronometer: Eos, Transactions of the American Geophysical Union, Electronic Supplement, v. 87, pp. V21A-0543.

Renne, P.R., Swisher, C.C., Deino, A.L., Karner, D.B., Owens, T.L., and DePaolo, D.J., 1998, Intercalibration of standards, absolute ages and uncertainties in ${ }^{40} \mathrm{Ar} /{ }^{39} \mathrm{Ar}$ dating: Chemical Geology, v. 145, pp. $117-152$.

Schärer, U., 1984, The effect of initial ${ }^{230} \mathrm{Th}$ disequilibrium on young $\mathrm{U}-\mathrm{Pb}$ ages; the Makalu case, Himalaya: Earth and Planetary Science Letters, v. 67, pp. 191-204.

Thorslund, P., and Jaanusson, V., 1960, The Cambrian, Ordovician, and Silurian of Västergötland, Närke, Dalarna, and Jämtland, central Sweden: International Geological Congress, 21st Session. Guide to Excursions Nos. A23 and C18, pp. 1-51.

Toghill, P., 1968, The graptolite assemblages and zones of the Birkhill Shales (Lower Silurian) at Dobb's Linn: Palaeontology, v. 11, pp. 654-668.

Toprak, F.Ö., Huff, W.D., and Bergström, S.M., in prep., The Lower Silurian (Llandovery) Osmundsberg K-bentonite in Baltoscandia and the British Isles: Chemical Fingerprinting and Regional Correlation.

Tucker, R.D., 1991, Ordovician and Silurian stratotypes in Britain, in Sutter, J.F., Zeittler, P.K. and Tucker, R.D., eds.,Thermochronology: applications to tectonics, petrology and stratigraphy. Geological Society of America Short Course Notes: U.S. Geological Survey Open File Report 91-565, pp. 57-58.
Tucker, R.D., Krogh, T.E., Ross, R.J., Jr., and Williams, S.H., 1990, Timescale calibration by high-precision U-Pb zircon dating of interstratified volcanic ashes in the Ordovician and Lower Silurian stratotypes of Britain: Earth and Planetary Science Letters, v. 100, pp. 51-58.

Tucker, R.D., and McKerrow, W.S., 1995, Early Paleozoic chronology: a review in light of new $\mathrm{U}-\mathrm{Pb}$ zircon ages from Newfoundland and Britain: Canadian Journal of Earth Sciences, v. 32, pp. 368-379.

Stig M. Bergström is Professor Emeritus of Geological Sciences at the School of Earth Sciences at the Ohio State University, USA, where he was teaching 1968-2005 after having received his graduate traning at Lund University, Sweden. He was a voting member of the International Subcommission on Ordovician Stratigraphy 1974-2004 and served as subcommission secretary in 1976-1982. His principal research interest is global Ordovician geology, especially aspects of the evolution of the Iapetus, the significance of LowerPaleozoic K-bentonites, and conodont and graptolite morphology and biostratigraphy.

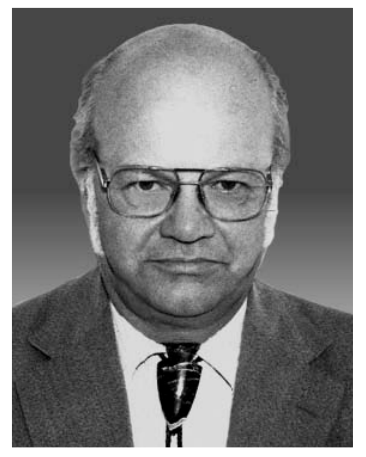

\section{Episodes is your window to the world. Subscribe today!}

\section{Episodes}

\section{Subscription Order}

Name (please print)

Address

City State/Prov.

Country Zip/Postal Code

Please begin my subscription:

$\begin{array}{llll}\text { March } & \text { June } & \text { Sept. } & \text { Dec. } \\ \text { Year } & \text { Year } & \text { Year } & \end{array}$

To start your subscription, fill in this form and mail to:

\section{Episodes}

P.O. Box 823

26 Baiwanzhuang Rd.,

Beijing 100037, China

Tel: +86-10-6832 0827; +86-10-68329084

Fax: +86-10-6832 8928

E-mail: episodes@public2.bta.net.cn
Payment may be made by:

- Checks (US \$ only) made payable to Episodes

- $\square \mathrm{JCB} \quad \square$ Visa

$\square$ American Express $\square$ Mastercard

Please quote account number, expiry date and signature.

Account\#

Expiry date

Signature

Annual subscription rates: US\$24 